\title{
砂〜シルト地盤に対する液状化対策としての セメント安定処理の効果に及ぼす粒度の影響
}

\author{
山本哲朗 1 - 山内智也 2 ・堀淵幸司 ${ }^{3}$ \\ 1正会員 工博 山口大学助教授 工学部社会建設工学科（广755 宇部市常盤台2557） \\ 2正会員 工修 (株) 鴻池組 東京本社（广101 東京都千代田区神田駿河台2-2-11） \\ ${ }^{3}$ 工修 大分県 $⿴$ 一杵土木事務所（８75 白杵市且杵洲崎72-254）
}

\begin{abstract}
砂〜シルト地盤に対する液状化対策エとしてのセメント安定処理の効果を土の粒度特性から調へるた めに, 砂からシルトの筑睴にある 6 種類の土試料を対象にして三軸セル室で 1日間圧密した処理土につ いて液状化実験を実施した。 その結果, 安定処理の勃果を表す指標として定義した液状化抵抗增加比 $R L$ は土の有效径 $D_{10}$ ともっとも良い相関にあって, 両者の関係はセメント添加率に強く依存する ことが明らかにされた.
\end{abstract}

Key Words : liquefaction, cement fixing agent method, grain size distribution, sand, silt

\section{1. まえがき}

近年, 飽和砂地盤の液状化防止対策としてセメン 卜安定処理工法を開発し, 利用するという立場から セメント安定材の種類と添加量, 養生（圧密）日数 といった諸因子に着目して, それらが特定の砂の液 状化抵抗に与える影響を調べるための基礎実験が実 施されている ${ }^{1) \sim 8)}$.

特に最近, 細粒分の多い埋立地盤に対してセメン 卜安定処理液状化対策工が実施されている ${ }^{9), 10)}$ とを勘案すれば, 土の粒度の違いによってセメント 安定処理の効果がどのように変化するのかを把握し ておくことが必要である. さらに, 土の粒度のどう いった指標とセメントの添加による土の液状化抵抗 の増加が関係するかを室内実験で予め検討しておけ ば, セメント安定処理工法を実地盤の液状化対策に 採用しようとする場合に基本となり，しかも有益な 指針が得られるはずである.

本研究は，こういう観点から液状化対策としての セメント安定処理の効果を土の粒度との関係から明 らかにすることを主目的にして繰返し三軸試験機を 用いた液状化実験を行った. そのため, 粒度分布の かなり異なり, 砂からシルトの範疇にある 6 種類の 土試料を用いた. セメントには 2 種類のものを用い て, その添加量を変えた.
本論文では最初にセメント処理土の液状化に達す るまでの有効応力経路, 応力ーひずみ関係を未処理 土のそれと比較しながら考察した. その後, 処理土 の液状化抵抗の增加比を表す指標として定義した $R L$ といくつかの土の粒度指標との関係を調へ， そ れはセメント添加率ごとに $10 \%$ 粒径 (有効径) $D_{10}$ と良い相関にあることを明らかにした.

さらに, 処理土の液状化抵抗と一軸圧縮強度の関 係, 処理土の土粒子構造および粒度分布に見られる 特徴を述べる.

\section{2. 实䀫に用いた土試料およびセメント}

粒度特性がかなり相違する 6 種類の試料を用いた. 表-1 はそれぞれの土の粒度指数を示し, 图-1 は粒 度曲線を示す．表-1 に記した順序，すなわち新宮 砂, 豊浦砂, シルト, 宇部岬シルト質砂, 宇部西沖 シルト, 宇部まさ土の順に粒度分布は悪い. シルト 以外の土は炬乾燥後, 表-1 の最大粒径 $D_{\max }$ で示す 大きさのふるいによって粒度調整して得られた．以 下に各土試料について簡単に説明する.

新宮砂は福岡県新宮町産の海浜砂であり, 豊浦砂 は山口県豊浦町産の海浜砂である. 現位置のシルト として, 宇部西沖シルトしか入手できなかったので, 豊浦砂をバンタムミル粉砕機で粉砕して人工的に得 
表-1 土試料の諸物理定数

\begin{tabular}{|c|c|c|c|c|c|c|}
\hline & $\begin{array}{c}\text { Shingu } \\
\text { sand }\end{array}$ & $\begin{array}{c}\text { Toyoura } \\
\text { sand }\end{array}$ & Silt & $\begin{array}{l}\text { Ubemisaki } \\
\text { silty sand }\end{array}$ & $\begin{array}{c}\text { Ubenishioki } \\
\text { silt }\end{array}$ & $\begin{array}{l}\text { Ube decomposed } \\
\text { granite soil }\end{array}$ \\
\hline$\overline{G_{s}}$ & 2.640 & 2.642 & 2.643 & 2.665 & 2.430 & 2.635 \\
\hline$U_{c}$ & 1.69 & 1.71 & 1.90 & 3.46 & 17.2 & 55.0 \\
\hline$D_{10}(\mathrm{~mm})$ & 0.45 & 0.12 & 0.035 & 0.052 & 0.005 & 0.02 \\
\hline$D_{50}(\mathrm{~mm})$ & 0.81 & 0.21 & 0.066 & 0.15 & 0.074 & 0.775 \\
\hline$D_{\max }(\mathrm{mm})$ & 2.00 & 0.84 & 0.106 & 2.00 & 2.00 & 4.75 \\
\hline $\begin{array}{ll}\mathbb{N}_{L} & (\boldsymbol{y}) \\
\end{array}$ & $\mathrm{NP}$ & $\mathrm{NP}$ & 35.8 & $\mathrm{NP}$ & 29.2 & 28.8 \\
\hline $\begin{array}{ll}W_{P} & (\%)\end{array}$ & $\mathrm{NP}$ & NP & $\mathrm{NP}$ & $\mathrm{NP}$ & 26.5 & $\mathrm{NP}$ \\
\hline$I_{P}$ & $\mathrm{NP}$ & $\mathrm{NP}$ & NP & NP & 2.7 & NP \\
\hline$e_{\max }$ & 0.851 & 0.941 & 1.261 & 1.027 & 1.518 & 0.950 \\
\hline$e_{\text {min }}$ & 0.624 & 0.643 & 0.722 & 0.658 & 0.852 & 0.673 \\
\hline$F_{c 1, y}(\%)$ & 0.0 & 0.0 & 0.0 & 0.0 & 9.0 & 5.0 \\
\hline FC (\%) & 0.0 & 0.0 & 62.5 & 13.3 & 51.7 & 16.4 \\
\hline & SP & SP & ML & SII & $\mathrm{ML}$ & SM \\
\hline
\end{tabular}

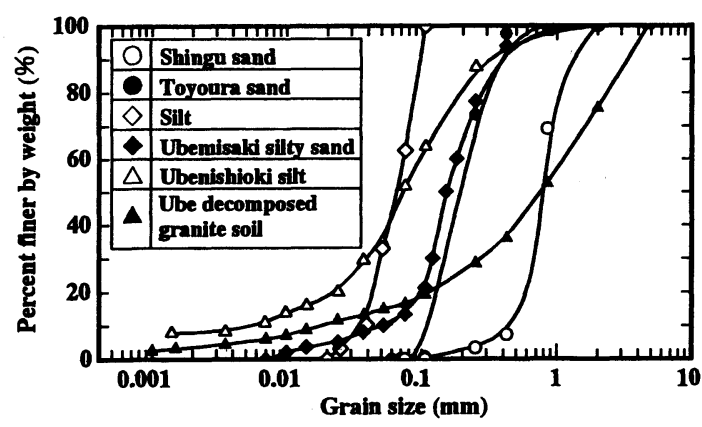

図-1 試料の粒度分布曲線

られたシルト（粒径 38〜106 $\mu \mathrm{m}$ ） も実験に用いる ことにした．このシルトの細粒分含有率 $F C$ は $62.5 \%$ ，他の土試料に比べてかなり大きい，宇部 岬シルト質砂は山口県の当地区の海底浚渫土である 宇部西沖シルトは, 当地区の埋立地盤においてボー リングコアから得られたものである. 宇部まさ土は 広島型花崗岩の風化したまさ土である.

土粒子形状の特徵として豊浦砂を粉砕して得られ たシルトは著しく角ばっているが，その他の土はや や角ばっているか, 丸味を帯びていることが挙げら れる。

セメントには, 普通ポルトランドセメント(以下、 $O P C$ と言う)および $U K C-H$ （（株）カルシー ド製）の 2 種類を用いた. $U K C-H$ は軟弱地盤に 対する安定処理材として開発され， $O P C$ に少量の
石亳を添加したものである. 両方のセメントとも比 重は 3.13 である.

\section{3. 英験装置および方法}

\section{（1）液状化実験装置}

実験には応力制御方式の繰返し三軸試験機を用い た.この試験機では直径約 $5 \mathrm{~cm}$, 高さ $12 \mathrm{~cm}$ の供試 体に作用させる正弦波状の繰返し軸差応力 $\left(\sigma_{d}\right)$ は, 復動式エアーシリンダーの上下の圧力室に所定の大 きさの空気圧を交番的に送り込んで発生させられる. その他の仕様の詳細は先の研究 ${ }^{11)}$ に譲る.

実験時には供試体に作用させる繰返し軸差応力, 供試体に生じる過剩間隙水圧（以下，間隙水圧とい う）および軸方向変位振幅を, それぞれロードセル (容量:490N), 間隙水圧計 (容量: $980 \mathrm{kPa}$ ), ダイヤル ゲージ式変位計 (容量: $20 \mathrm{~mm}$ ) で測定した。

\section{（2）実験方法}

\section{a) 液状化実験}

供試体の作製は以下の方法で行った. 所定量の土 試料に脱気水を満たし，良く擋汼しながら 2 時間ほ ど湯煎煮沸を行い，土粒子間の空気を除去する. セ メントを添加しない未処理土の場合には, この脱気 した土試料を水中落下法でゴムスリーブに詰めて飽 和供試体を作製した。 一方, セメントを添加した処 理土の場合は, 所定量のセメントを混合した土試料 を同様の方法で詰めて飽和供試体を作製した．その 際にはセメントと土とが均質になるように混合し， それを少量ずつゴムスリーブに詰めて，均質なセメ ント混合処理土を得るよう心がけた。 
セメント添加率 $C$ は土試料の乾燥重量に対する セメントの重量百分率で表わすことにし, 通常の実

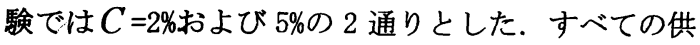
試体の乾燥単位体積重量 $\gamma_{d}$ は $12 \sim 15 \mathrm{kN} / \mathrm{m}^{3}$ の範囲 にあった.

その後, 拘束圧 $\sigma_{30}=98 \mathrm{kPa}$, 背圧 $\sigma_{b}=49 \mathrm{kPa}$ を供 試体に作用させて, その際の間隙圧係数 ( $B$ 值) は 0.96 以上であることを確認した。この $B$ 值はセメ ントを添加しない供試体のそれと同程度であった。 その後, 有効拘束圧 $\sigma_{30}^{\prime}=49 \mathrm{kPa}$ の下で 1 日間供試体 の圧密を行った. 圧密終了後に，周期 2 秒で振幅の 大きさが一定の繰返し軸差応力を供試体に液状化が 生じるまで作用させた。本文では一般に行われてい るように，供試体の軸ひずみ両振幅が $5 \%$ に達した 時をもって液状化による破壊が発生したものと判定 した.

通常, 飽和砂地盤の液状化は $10 \mathrm{~m}$ 以浅で発生する ことが多いので， $\sigma_{30}^{\prime}$ は $49 \mathrm{kPa}$ に設定した. また， 圧密ないし養生日数の増加に伴ってセメント処理土

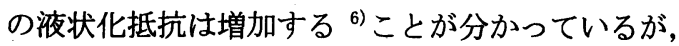
本実験では多くの種類の土について多くのデータを 得なければならないという必要性からすべての実験 で圧密日数は 1 日に限定した.

\section{b)一軸圧縮試験}

処理土の液状化抵抗と一軸圧縮強度の関係を調べ るために, 一軸圧縮試験を行った. 液状化実験の場 合と全く同様に 1 日圧密によって処理土供試体を作 製した後, ゴムスリーブをカッターナイフで注意深 く切り裂いて得られた供試体を実験に用いた。軸ひ ずみ速度は $1 \% / \mathrm{min}$ とした。

\section{c) 走查型電子顕微鏡観察}

処理土の土粒子構造を見るために走査型電子顕微 鏡観察を行った.

\section{4. 結果および考察}

\section{（1）処理土および未処理土の典型的な液状化実験 記録}

6 種類の土試料の中でセメント添加による液状化 抵抗の増加が最も室少であった新宮砂について, 未 処理土および処理土供試体の典型的な液状化実験記 録波形を.それぞれ图-2(a)，2(b)に示す. 両方の実験 とも応力比 $\sigma_{d} / 2 \sigma_{30}^{\prime} \fallingdotseq 0.2$ で行われた. 処理土は $O P C$ を $C=2 \%$ 添加したものである. 記録線は上か ら順に, 供試体の軸ひずみ $\varepsilon_{1}$, 繰返し軸差応力 $\sigma_{d}$, 間隙水圧 $\boldsymbol{u}$ を示す. 軸ひずみおよび軸差応力の符号 は圧縮側が正，伸張側が負である.
両図を比べて分かるように, 両方の供試体におい て繰返し載荷回数に伴う軸ひずみおよび間隙水圧の 上昇の様子はきわめてよく似ている．このように， 新宮砂のように比較的粗い粒子からなる粒度分布の 悪い砂では $O P C$ を $C=2 \%$ 程度添加してもセメント による土粒子間の固結は生じないため, 液状化抵抗 は増加しないと言える.

一方，人工的に作ったシルトを除いてセメシトの 添加による液状化抵抗の増加が最も顕著であった宇 部西沖シルトについて未処理土および処理土の典型 的な記録波形をそれぞれ図-3(a)，3 (b) に示す。この 末処理土では小さい繰返しせん断応力 $\left(\sigma_{d} / 2 \sigma_{30}^{\prime}=0.121\right)$ の下で液状化が発生している. これに対して, 処理土では大きな繰返しせん断応力

$\left(\sigma_{d} / 2 \sigma_{30}^{\prime}=0.632\right)$ を作用させているため, せん 断初期から軸ひずみ掁幅は漸増する傾向が見られる ものの, 液状化後も間隙水圧は決して有効拘束圧に 等しくならない. また, 正のダイレイタンシーに よって一時的に間隙水圧は負またはゼロとなり, 土 粒子間の有効応力は初期状態の值まで回復している. この現象は密な砂あるいは粘性土の液状化実験の時 に観察されるサイクリックモビリティーと同じもの である. この原因は後述するように, セメントの添 加によって特に細かい土粒子間が固結して土粒子構 造が安定となるためと考えられる.

\section{（2）処理土および未処理土の有効応力経路, 応カー ひずみ関係}

图-4 (a)，4(b) はそれぞれ新宮砂の未処理土および 処理土供試体の有効応力経路を示す. 同様に, 図一 5 (a)，5 (b) は繰返し軸差応力一軸ひずみ関係を示す. これらの図中, 有効平均主応力 $p^{\prime}$ およ゙軸差応力 $q$ は式（1）で与えられる.

$$
\left.\begin{array}{l}
p^{\prime}=\frac{\sigma_{a}^{\prime}+2 \sigma_{r}^{\prime}}{3} \\
q=\sigma_{a}^{\prime}-\sigma_{r}^{\prime}
\end{array}\right\}
$$

ここで $\left(\sigma_{a}^{\prime}, \sigma_{r}^{\prime}\right)$ はそれぞれ有効応力表示による 軸方向応力および半径方向応力である.

図-4(a)，4 (b) から分かるように, セメントの添加 による液状化抵抗の増加の見られない新宮砂の処理 土の場合は, 未処理土と同様に有効応力が繰返し載 荷回数に伴って減少し, 液状化時にほぼゼロとなる. この実験も含め, 以下の実験での有効応力経路図が やや上方に位置するのは, 圧縮側の繰返し軸差応力 が引張り側よりも若干大きいためである。また図- 


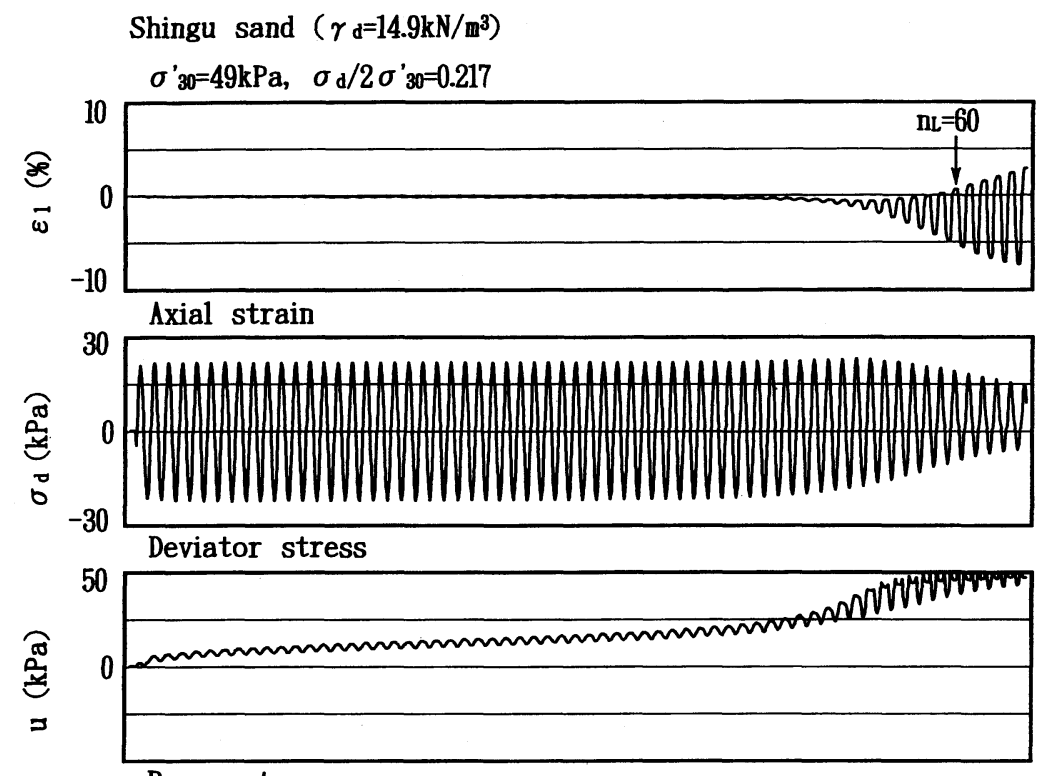

Pore water pressure

図-2（a）新宮砂未処理土の液状化実験の記録波形

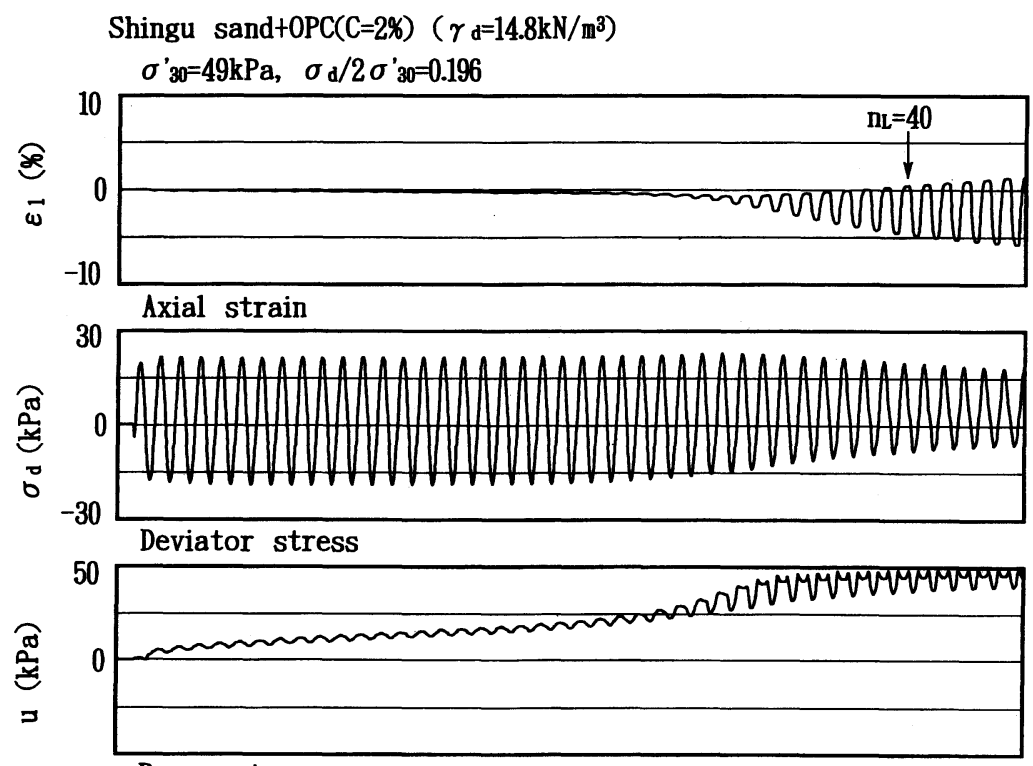

Pore water pressure

図-2 (b) 新宮砂処理土（OPC $(C=2 \%) ）$ の液状化実験の記録波形

5 (a) 5 (b) から分かるように, 未処理土, 処理土の 違いはほとんどなく，ともに軸ひずみは伸張側に增 加する.

図-6 (a)，6 (b) はそれぞれ宇部西沖シルトの未処理 土および処理土供試体の有効応力経路を示す. 图一
7 (a)，7(b) は軸差応力ー軸ひずみ関係を示す．图一 7 (a), 7(b)を比較して分かるように, セメシトの添 加による液状化抵抗の増加の著しい処理土では, 上 述した理由によって有効平均主応力は消失すること はない。 


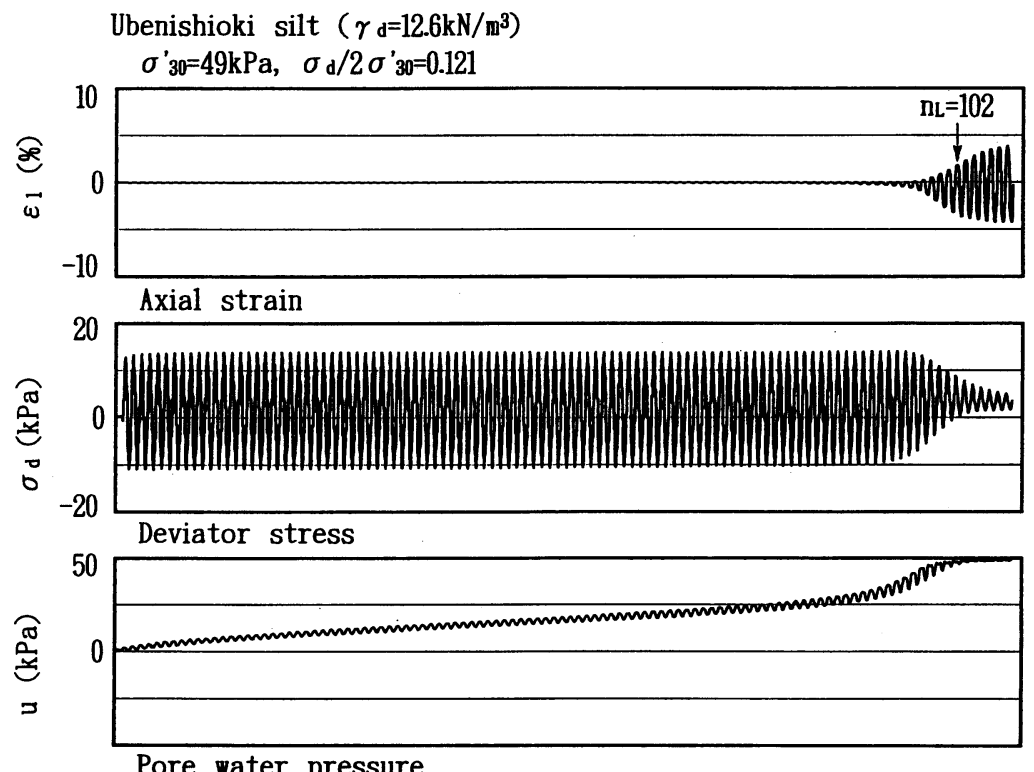

図-3 (a) 宇部西沖シルト未処理土の液状化実験の記録波形

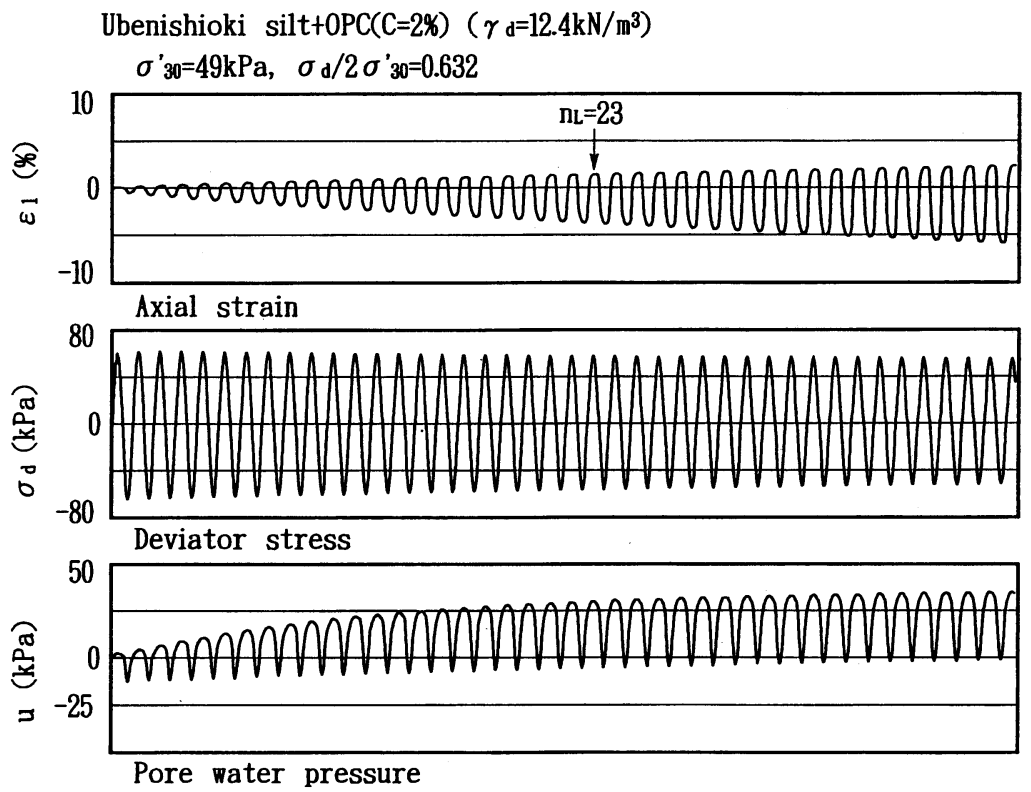

図-3 (b) 宇部西沖シルト処理土（OPC $(C=2 \%))$ の液状化実験の記録波形

また，図-7(a)の未処理土の場合，ある繰返し載 荷回数で軸ひずみは急増し始め, 液状化後は軸差応 力振幅の減少は顕著となるが, 図-7(b)の処理土の 場合には図-3(b) のところで述べたように，この実 験で繰返しせん断応力が大きいために大きな軸ひず
み振幅が 1 サイクル目から発生し, 伸張側にその振 幅が漸増するものの, 軸差応力の振幅の减少はそれ ほど生じない.

このように, セメントの添加によって液状化抵抗 の増加が顕著に見られる宇部西沖シルトの場合には 


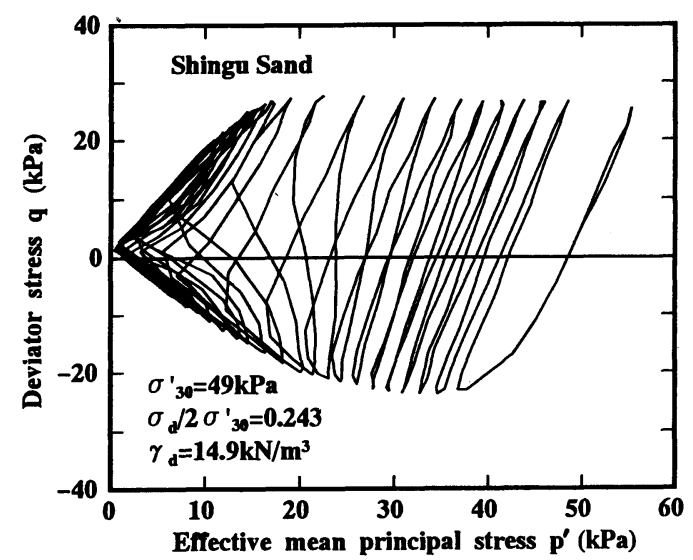

図-4 (a) 新宮砂の有効応力経路

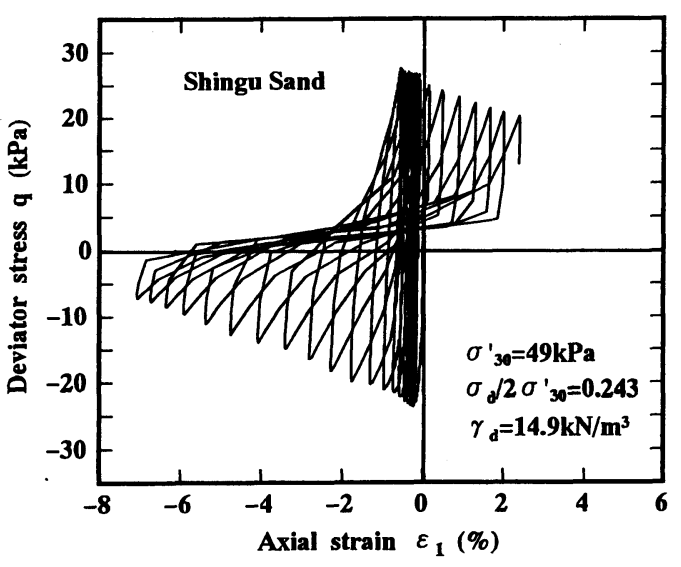

図-5(a) 新宮砂未処理土の軸差応力ーひずみ曲線

処理土の有効応力経路および繰返し軸差応力一軸ひ ずみ曲線は未処理土の場合と著しく相違することが 明示された。

\section{(3) 各処理土の $\sigma_{\mathrm{d}} / 2 \sigma^{\prime}{ }_{30}$ と $\mathrm{n}_{\mathrm{L}}$ の関係}

各土試料毎に $O P C$ および $U K C-H$ をそれぞれ $C=2 \%, C=5 \%$ 添加した処理土の一連の液状化実験 から得られた応力比 $\sigma_{d} / 2 \sigma_{30}^{\prime}$ と液状化を生じるま での繰返し載荷回数 $n_{L}$ の関係（以下, 液状化抵抗 曲線と呼ぶ）を図-8(a)〜8(f)に示す．なお，宇部

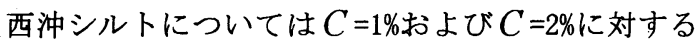
関係が示されている.これらの図には比較のため, 末処理土 $(C=0 \%)$ の結果も示す. なお, 処理土では

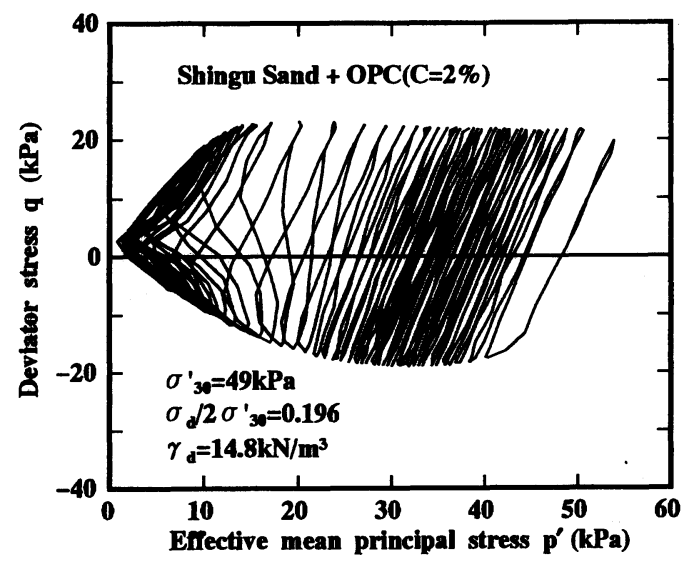

図-4(b) 新宮砂 $(\mathrm{OPC}(\mathrm{C}=2 \%))$ の 有効応力経路

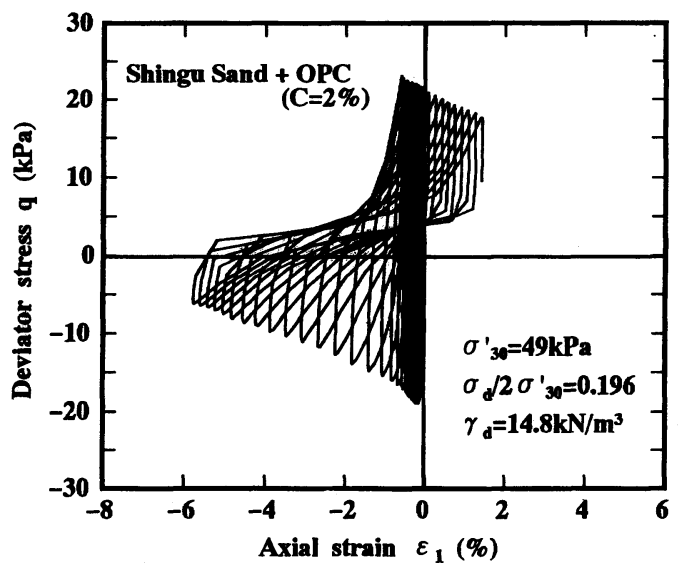

図-5(b) 新宮砂処理土（ $\mathrm{OPC}(\mathrm{C}=2 \%))$ の 軸差応力ーひずみ曲線

土粒子間の間隙に僅かな量のセメントが均質に混入 された状態での相対密度を正確に決定することは困 難である. そのため, 結果の整理ではそれに代わり 乾燥単位体積重量 $\gamma_{d}$ を用いた.

以下に, 個々の土試料毎に結果を少し詳しく述べ る.最初に図-8（a)に示した新宮砂においては, $O P C$ および $U K C-H$ を $C=2 \%$ 添加した処理土の 液状化抵抗曲線はセメントの種類にかかわらず未処 理土のそれと全く同じであり， $n_{L}=20$ 回の応力比 で与えられる液状化抵抗 $R_{20}$ はセメントの添加に よって全く増加しないことが分かる. また， $O P C$ を $C=5 \%$ 添加した場合には処理士の液状化抵抗は僅 かに増加するが，他の土試料に比べてその割合は 


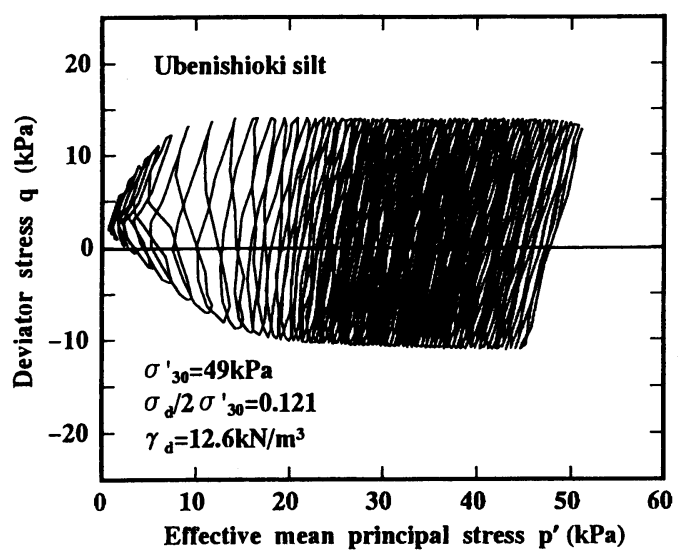

図-6 (a) 宇部西沖シルト未処理土の有効応力経路

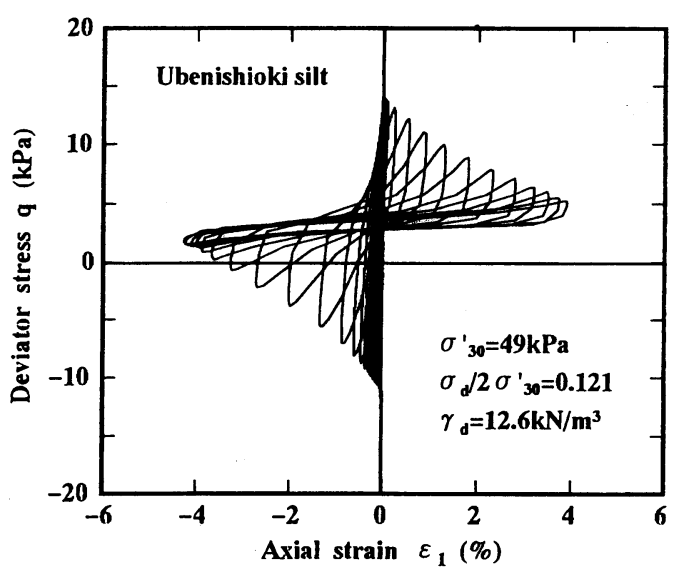

図-7(a) 宇部西沖シルト未処理土の 軸差応力ーひずみ曲線

もっとも小さい.

図-8(b) の豊浦砂においては，処理土の液状化抵 抗曲線は未処理土のそれよりもかなり上位にあるこ とが分かる。そして $U K C-H$ あるいは $O P C$ を

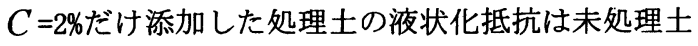
の場合に比べて 1.6 倍, 1.3 倍ほど大きいことが分 かる.

図-8(c)のシルトの場合は, 他の土試料に比べて $C=5 \%$ 処理土の液状化抵抗曲線は未処理土のそれ よりもかなり上位にあるのが注目される.すなわち, $O P C$ を添加した場合は未処理の場合よりも 4.1 倍, $U K C-H$ を添加した場合は 5.6 倍ほど液状化抵抗 は大きい。この原因はシルトは豊浦砂を粉砕して人 工的に作った土試料であるので, 破砕した土粒子表

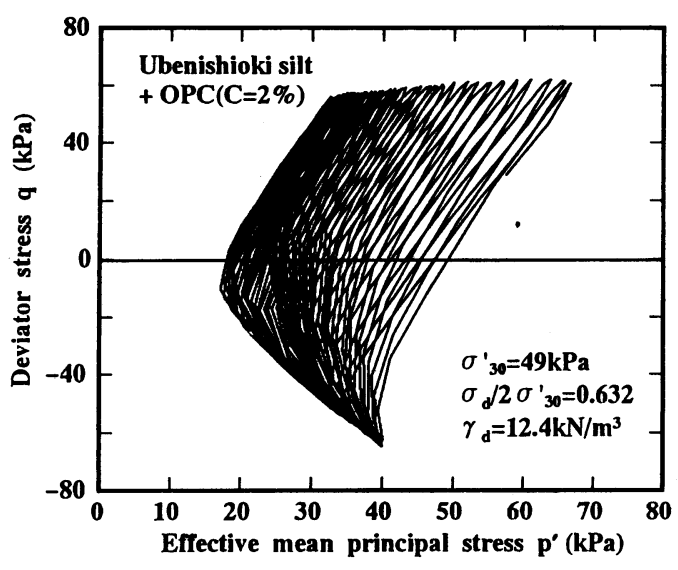

図-6 (b) 宇部西沖シルト処理土（OPC（C=2\%））の 有効応力経路

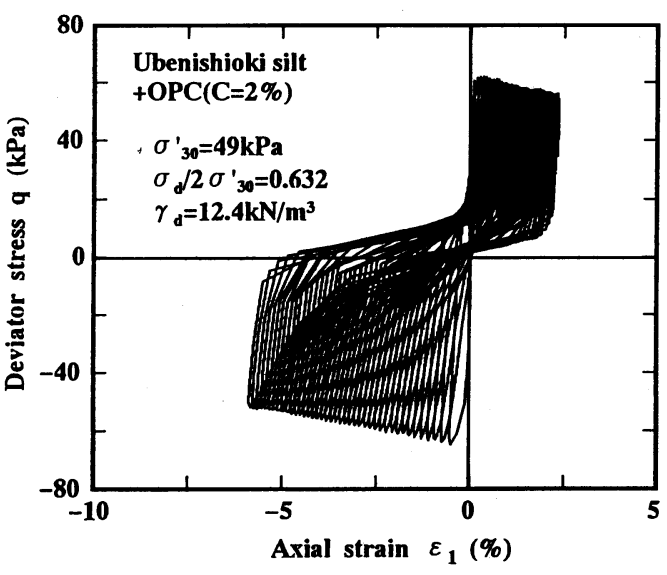

図-7(b) 宇部西沖シルト処理土（OPC $(\mathrm{C}=2 \%))$ の 軸差応力ーひずみ曲線

面が新鮮で，しかも凹・凸に富んでいるためにセメ ントによる土粒子間の固結の度合いが他の土試料に 比較して著しく大きいためと考えられる.

図-8(d) の宇部岬シルト質砂の場合は他の土試料 とは異なり，UKC-Hよりも $O P C$ を添加した方 が液状化抵抗の増加が大きくなっている．例えば $O P C, U K C-H$ をそれぞれ $C=5 \%$ 添加した処理 土の液状化抵抗は未処理土よりも 4.0 倍, 3.3 倍大 きい.このシルト質砂は現位置で採取した時点では $p H=3$ 程度であったが，他の土と同じように $p H=6$ 程度となるように水酸化ナトリウムを加え たために，このような結果が得られたのか，あるい は他の理由によるものかは今の段階では明らかにす ることはできなかった. 


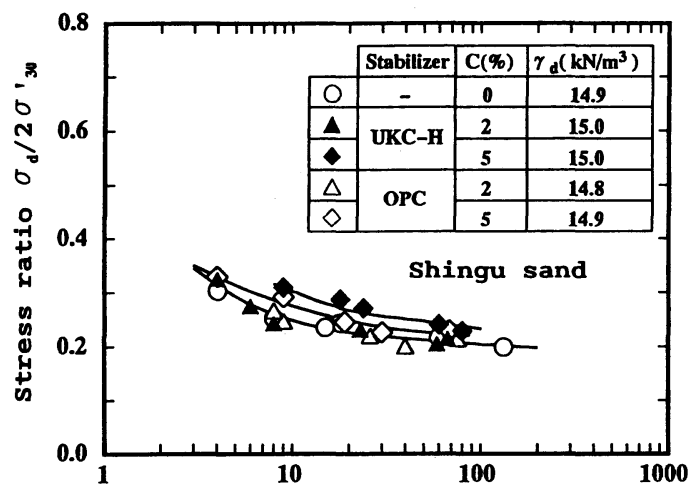

Number of cycles to cause liquefaction $n_{L}$

図-8（a） 新宮砂

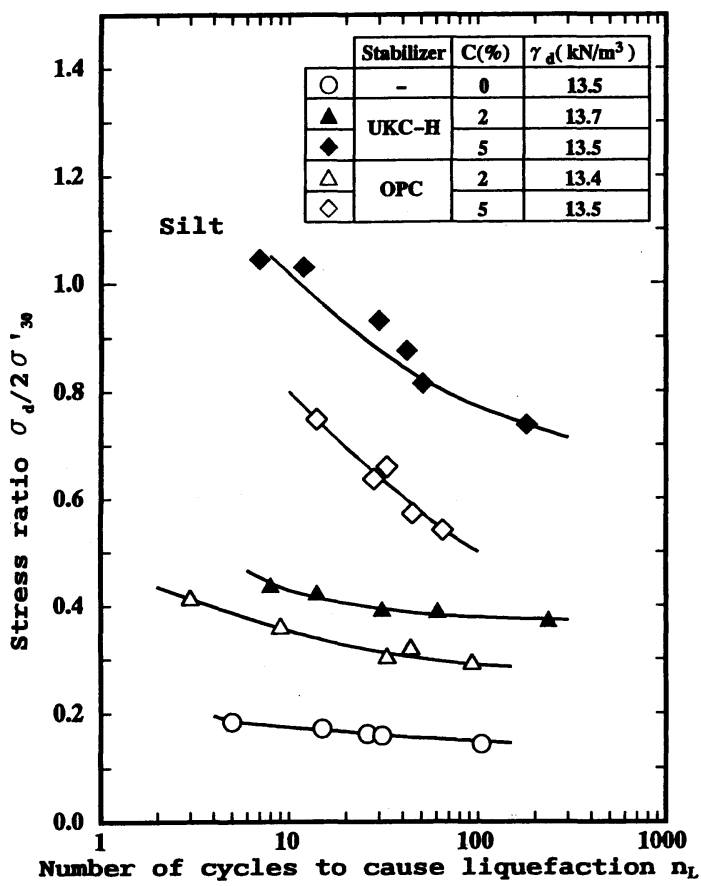

図-8(c) シルト

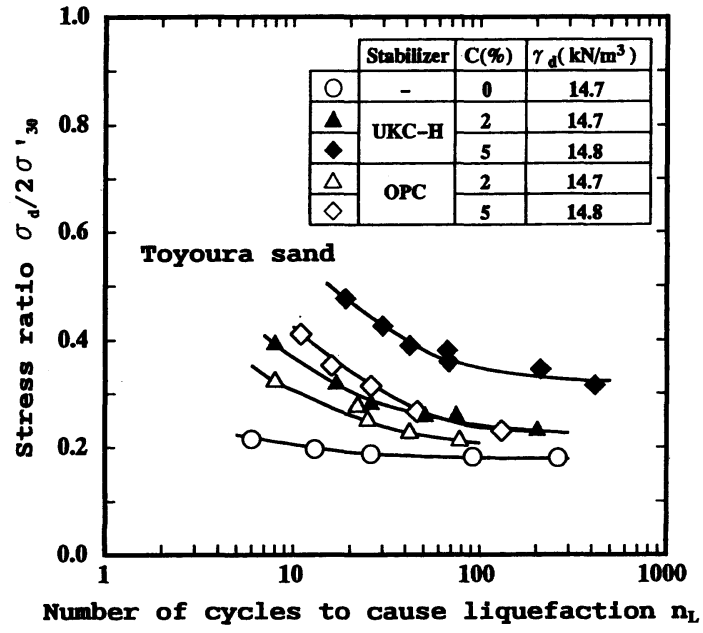

図-8(b) 豊浦砂

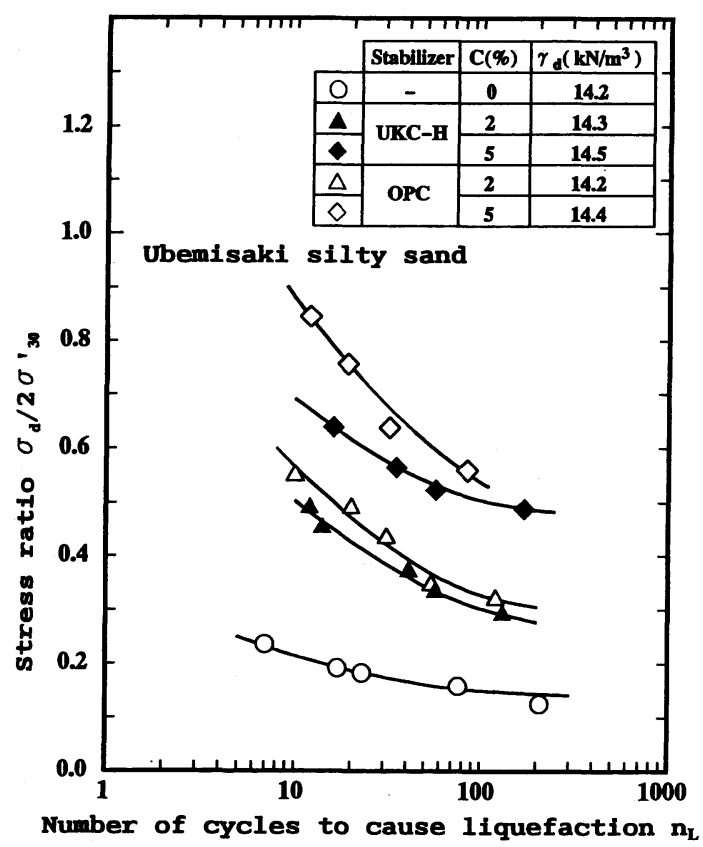

図-8 (d) 宇部岬シルト質砂
図-8 (a) （f） セメントの種類および添加率 C を 変えた各土試料に対する繰返し応力 比 $\sigma_{\mathrm{d}} / 2 \sigma^{\prime}{ }_{30}$ と液状化を生じるまで の繰返し載荷回数 $\mathrm{n}_{\mathrm{L}}$ の関保 


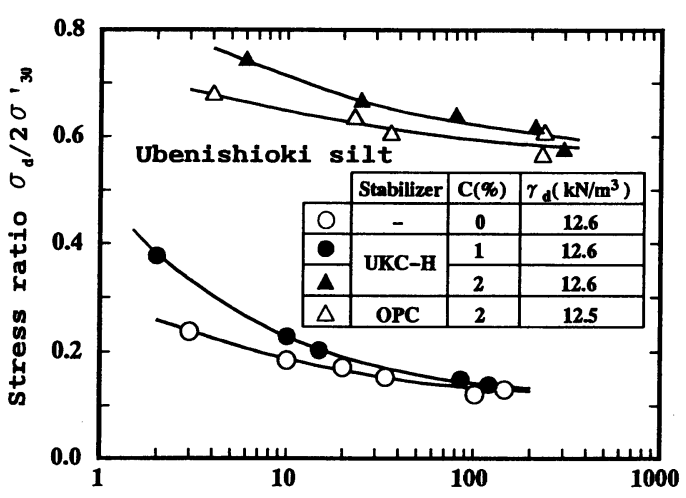

Number of cycles to cause liquefaction $n_{L}$

図-8（e） 宇部西沖シルト

図-8(e)の宇部西沖シルトでは $U K C-H$ および $O P C$ を $C=2 \%$ 添加した場合の液状化抵抗は，それ ぞれ未処理土よりも 4.0 倍, 3.8 倍大きくなってお り，既に述べたように，人工のシルトを除いて本実 験で用いた土試料の中で最もセメント安定処理の効 果は大きい土試料である.

最後の図-8(f)のまさ土の場合はセメントの種類 によって液状化抵抗の増加には差異はほとんど見ら れない. すなわち， $C=2 \%$ おび $5 \%$ の両方のセメン トによる処理土の液状化抵抗は未処理土よりもそれ ぞれ 2.8 倍, 3.9 倍大きい.

以上の実験結果から，細粒分が多くて粒度の良い 宇部西沖シルトでは $C=2 \%$ 場合でも液状化対策と してのセメント安定処理の効果は顕著であるが, 粗 粒分が多くて粒度の悪い新宮砂では $C=5 \%$ もその 効果はあまり期待できないという結論が得られた.

また, シルトに見られるように土粒子の表面状態 によって，あるいは宇部岬シルト質砂に見られるよ うに土の $p H$ 值によってセメント安定処理の効果 が異なる可能性のあることが示された．この点は今 後さらに検討を要する.

\section{（4）処理土の液状化抵抗増加比 RL に関与する} 粒度指数についての検討

(3)の検討でセメントの添加による液状化抵抗の 増加の程度は本質的には土の粒度に依存することが 示唆された. 次に, その増加が土の粒度のどういっ た指数に関与しているか検討を行った.

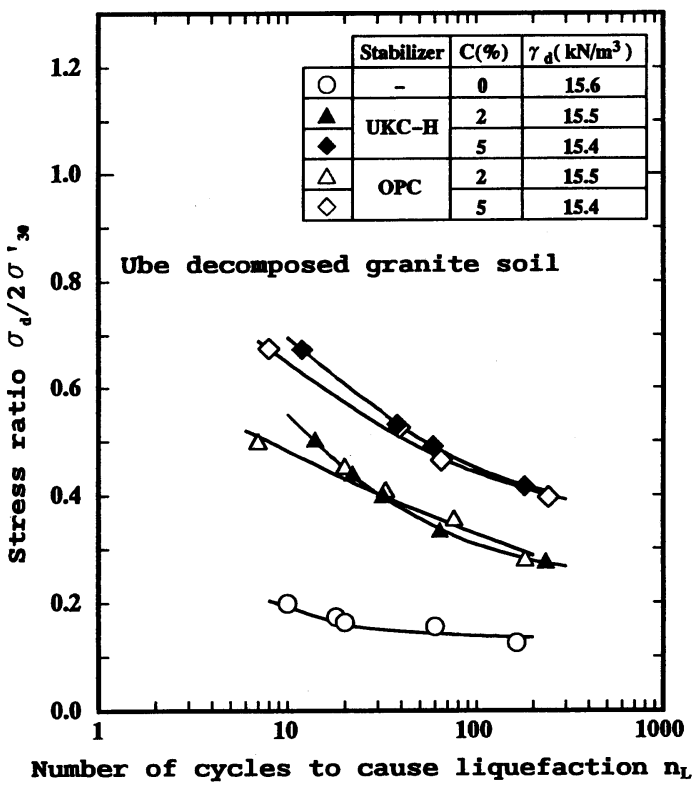

図-8（f） 宇部まさ土

セメント安定処理の効果を表す指標として液状化 抵抗增加比 $R L$ (式 (2)) を定義し, これと均等係数 $U_{c}$, 細粒分含有率 $F C$, 平均粒径 $D_{50}$ および有効 径 $D_{10}$ との関係を調べ，それぞれ図-9１2 に示し た結果を得た。

$$
R L=\frac{\left(R_{20}\right)_{C}-\left(R_{20}\right)_{C=0}}{\left(R_{20}\right)_{C=0}}
$$

ここで, $\left(R_{20}\right)_{C},\left(R_{20}\right)_{C=0}$ はそれぞれ処理土お よび未処理土供試体の液状化抵抗を表す。

図-9,10,11 から $R L$ はそれぞれ $U_{c}, F C, D_{50}$ とは良い相関関係にないことが分かる. なお，ここ には図示していないが, 最大粒径 $D_{\max }$ とも良い相 関はなかった。

一方，図-12 から若干のデータのばらつきはある

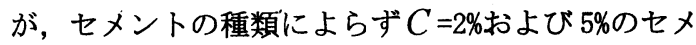
ント添加率毎に， $D_{10}$ が小さいほど， $R L$ は大きく なるという良い相関が両者間に認められる. 前述し たように，人工的に作ったシルトについてはセメン 卜安定効果が他の現位置の土試料よりも高いので, その $R L$ 值は他より突出している.

$R L$ が $D_{10}$ と良い相関にあるのは以下のように解 


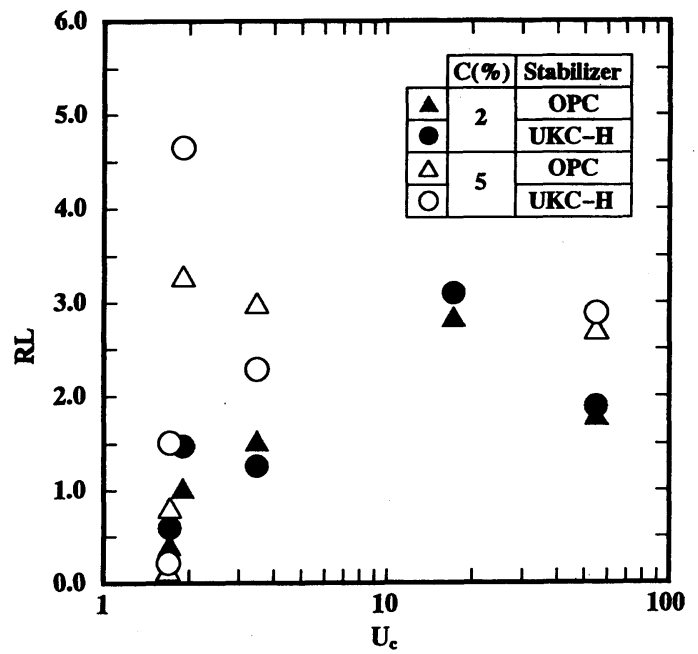

図-9 処理土の RL と $U_{c}$ の関係

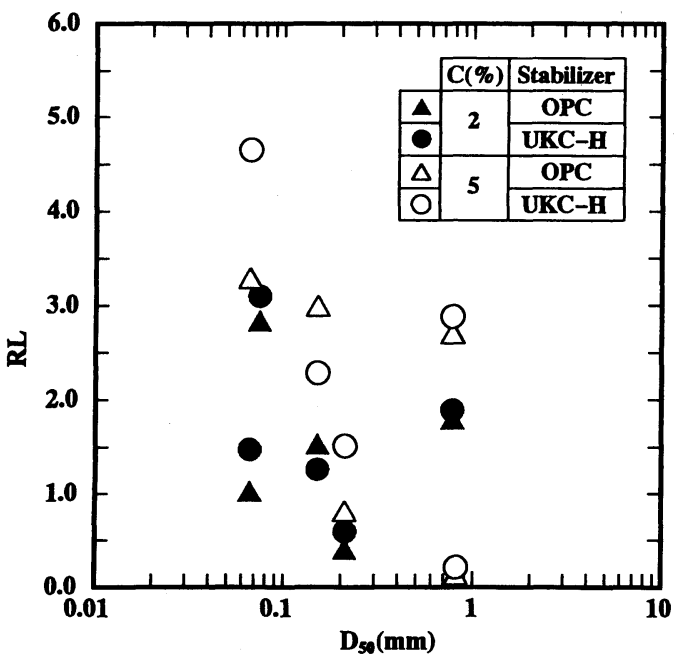

図-11 処理土の RL と $\mathrm{D}_{50}$ の関係

釈される. 後述の土粒子構造の走査型電子顕微鏡写 真に見られるように，セメントを添加した土粒子表 面およびその間にはセメント水和物が生成して，土 粒子間が固結される. $C=2 \%$ るいは $5 \%$ というう にセメント添加率があまり大きくない場合には土粒 子径が小さいほど, この固結の度合いが大きく, 土 粒子構造が安定になるため, 液状化を生じ難くなる と考えられる. 土の粒度指数の内で $D_{10}$ は他よりも 細かい粒子の大きさを代表する指標であるので，こ

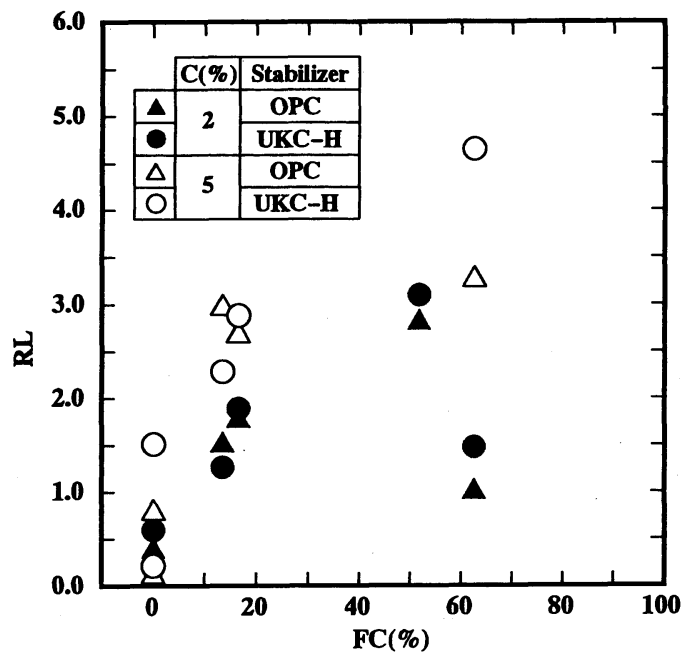

図-10 処理土の RL と FC の関係

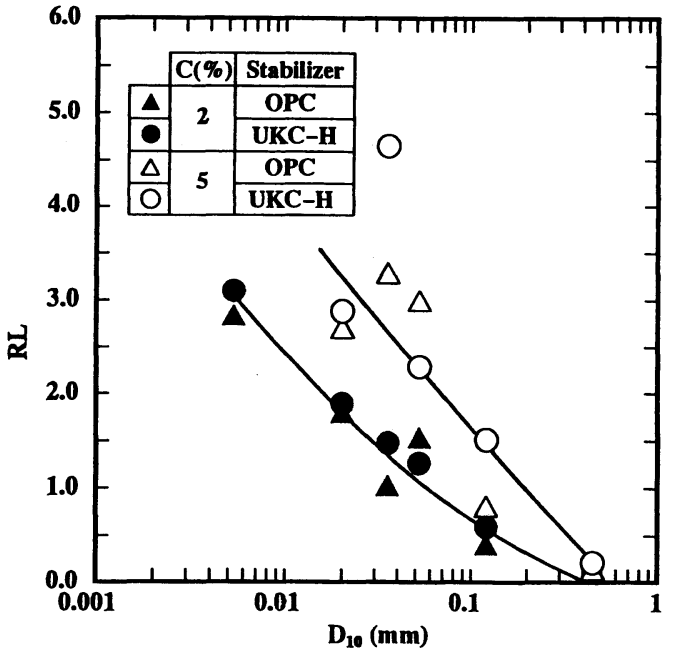

図-12 処理土の RL と $\mathrm{D}_{10}$ の関係

れが $R L$ に関与すると考えられる.

なお，土の間隙比の大きさ，言い換えると土の骨 格構造に関係する砂の透水係数は $D_{10}$ を用いて簡易 的に推定される.

以上のように, 本実験において $R L$ は $D_{10}$ と最も 良い相関があるという興味ある結果が得られたので, 過去に他の研究者によって得られた実験結果につい ても同様に検討した。 その結果は図-13 に示す.す

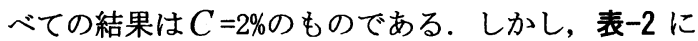




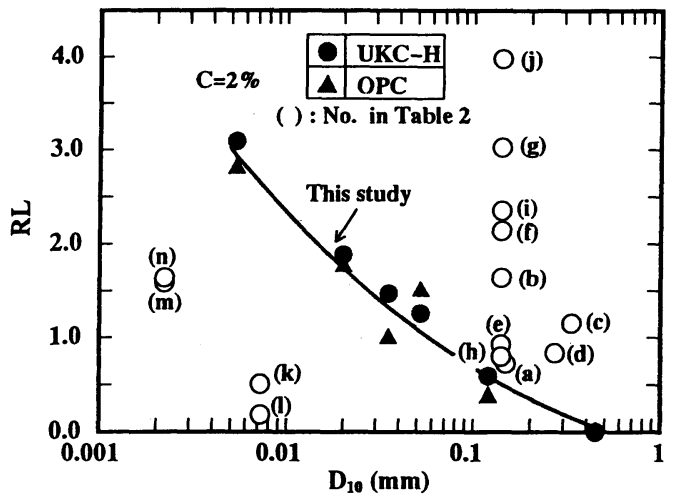

図-13 過去の研究から得られた RL と $D_{10}$ の関係

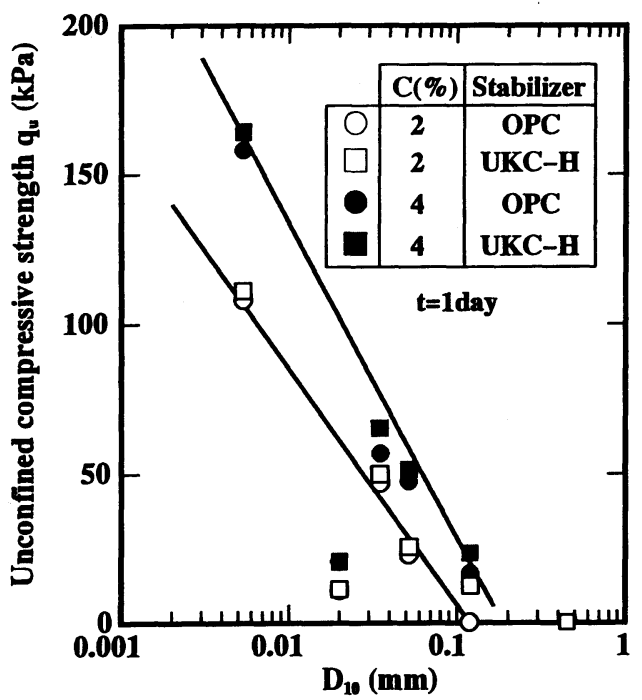

図-14 一軸圧縮強度 $\mathrm{q}_{u}$ と $\mathrm{D}_{10}$ の関係

示すように，個々の実験毎に用いたセメントの種類， 供試体の養生または圧密日数 $t$ および圧密圧の大き さが異なることもあって, 図-13 からは $R L$ と $D_{10}$ の間には良い相関を得ることはできなかった，ただ，

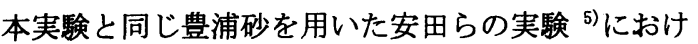
る No. e および No. $\mathrm{h}$ の $R L$ 值は本実験で得た值に近 いものであった.

\section{(5) 処理土の液状化抵抗と一軸圧縮強度の関係}

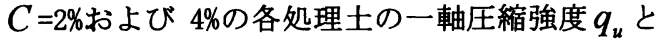
$D_{10}$ の関係を調べた結果を図-14 に示す.すべての
表-2 過去の研究における試料,セメント および試験条件

\begin{tabular}{|c|l|c|c|c|c|}
\cline { 2 - 6 } \multicolumn{1}{c|}{} & \multicolumn{1}{|c|}{ Sample } & Stabilizer & $\begin{array}{c}\sigma \text { so } \\
(\mathrm{kPa})\end{array}$ & $\begin{array}{c}\mathrm{t} \\
(\text { days })\end{array}$ & $\begin{array}{c}\text { Reference } \\
\text { No. }\end{array}$ \\
\hline a & Niigata EP sand & PBSC typeB & $?$ & 34 & $2)$ \\
\hline b & Toyoura sand & OPC & 98 & 2 & $3)$ \\
\hline c & Monterey No. 0/30 & PCtype II & $?$ & 14 & $4)$ \\
\hline d & Monterey No. 0 & PCtype I & 98 & 15 & $5)$ \\
\hline e & Toyoura sand & OPC & 49 & 1 & $7)$ \\
\hline f & Toyoura sand & OPC & 49 & 7 & $7)$ \\
\hline g & Toyoura sand & OPC & 49 & 28 & $7)$ \\
\hline h & Toyoura sand & Sorstar & 49 & 1 & $7)$ \\
\hline i & Toyoura sand & Sorstar & 49 & 7 & $7)$ \\
\hline j & Toyoura sand & Sorstar & 49 & 28 & $7)$ \\
\hline k & Chiba Mt. sand & OPC & 49 & 7 & $7)$ \\
\hline I & Chiba Mt. sand & Sorstar & 49 & 7 & $7)$ \\
\hline m & Deconposed granite & OPC & 49 & 7 & $7)$ \\
\hline n & Decomposed granite & Sorstar & 49 & 7 & $7)$ \\
\hline
\end{tabular}

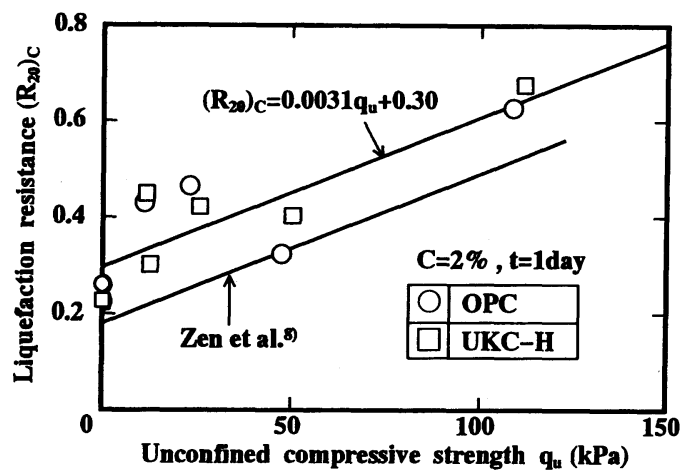

図-15 処理土の液状化抵抗と一軸圧縮強度の関係

新宮砂処理土, また $O P C$ を $C=2 \%$ 添加した豊浦砂 処理土では圧密後にゴムスリーブを取り外す際に供 試体は崩壊し，一軸圧縮試験を行うことができな かった. その結果は $q_{u}=0$ の点で示した. 図-14 か らそれぞれのセメント添加率に対して処理土の $q_{u}$ は $D_{10}$ の対数值に比例して減少することが分かる.

また，両者の関係にはセメントの違いによってほと んど差異は見られない. セメントの添加によって一 軸圧縮強度が増加するのは，一般に土粒子間に生じ た固結に起因する見かけの粘着力によると考えられ ている ${ }^{8), 12)}$.

$C=2 \%, t=1$ 日の各処理土の液状化抵抗と一軸圧 縮強度の関倸を調べた結果を図-15に示す. $q_{u}$ が 小さい範囲では両者の関係には若干のばらつきがあ

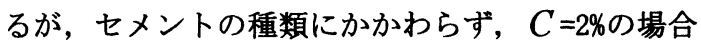
の両者の関係は次式によって与えられよう． $q_{u}$ の 単位は $\mathrm{kPa}$ である. 


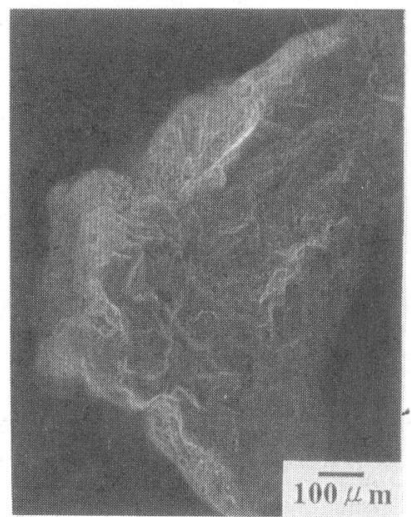

写兵-1（a） 新宮砂未処理土の電子顕微鏡写真

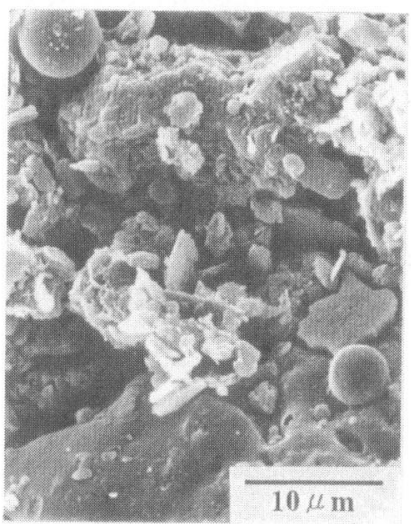

写㥲-2（a） 宇部西沖シルト未処理土の電子顕微鏡写真

$$
\left(R_{20}\right)_{C}=0.0031 q_{u}+0.30 \quad(C=2 \%)
$$

なお，セメント処理土の液状化抵抗と一軸圧縮強

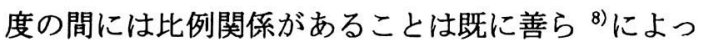
て指摘されている. その関係を図-15 に示す，その 実験では砂およびまさ土の $C=2 \%$ 処理土供試体は 海水中で 28 日間養生された。このように，著者ら と彼らの実験では試験条件が大幅に違うが, ある条 件のもとではセメント処理土の液状化抵抗は一軸圧 縮強度を用いてある程度予測できる可能性が示され たことは興味深い.

\section{（6）処理土の土粒子權造および粒度分布}

走査型電子顕微鏡を用いてセメント処理土および 未処理土の土粒子構造を観察した。 その一例として 新宮砂および宇部西沖シルトに $O P C(C=2 \%)$ を添 加した処理土の結果を示す.

まず新宮砂については写真-1 (a) に示す未処理土

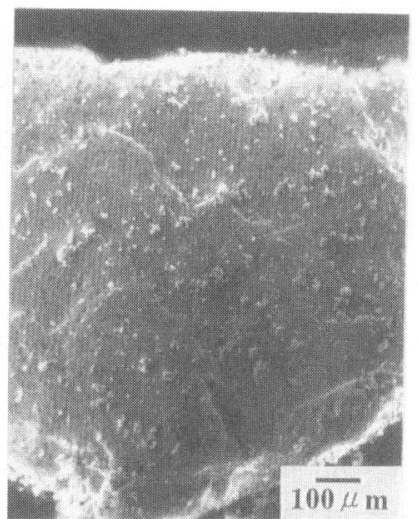

写真-1 (b) 新官砂処理土（OPC (C=2\%)) の 電子影微鏡写真

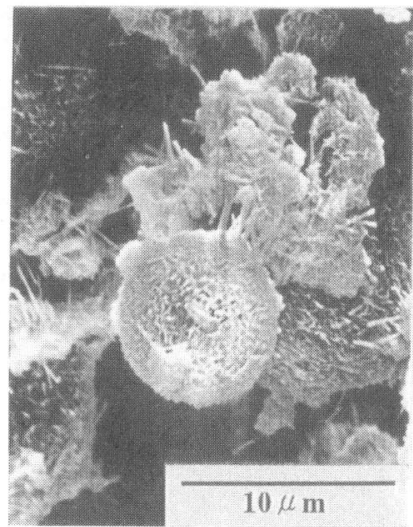

写真-2 (b) 宇部西沖シルト処理土 $(\mathrm{OPC}(\mathrm{C}=2 \%))$ の 電子顕微鏡写真

の場合(倍率 100 倍) と比較して, 写真-1 (b) に示す 処理土(倍率 100 倍)では, 土粒子表面に網目状の珪 酸石灰水和物 (以下, $C-S-H$ と言う) が固結し ているのが分かる.この写真では, 土粒子間の状況 は分からないが， $C-S-H$ によって土粒子間が 固結している状態は観察されなかった。

宇部西沖シルトの場合は，写真-2 (a)に示す未処 理土(倍率 3,000 倍) と比較して, 写真-2(b)に示す 処理土の場合(倍率 4,500 倍)には，土粒子の表面に $C-S-H$ が生成し，また針状のアルミン酸硫酸 石灰水和物 (以下，エトリンガイトと言う）が土粒子 同士を結合させている様子が観察される ${ }^{13)}$ 。この ようなエトリンガイトの生成によって，土粒子が三 次元的に結合され, さらにC-S-Hの生成に よって, 土粒子間の間隙が狭められて密実で堅固な 土粒子構造が形成されるためにセメント処理土の強 度増加が発現することは既に分かっている ${ }^{13)}$.

今回の観察の範囲においては，新宮砂のように粗 


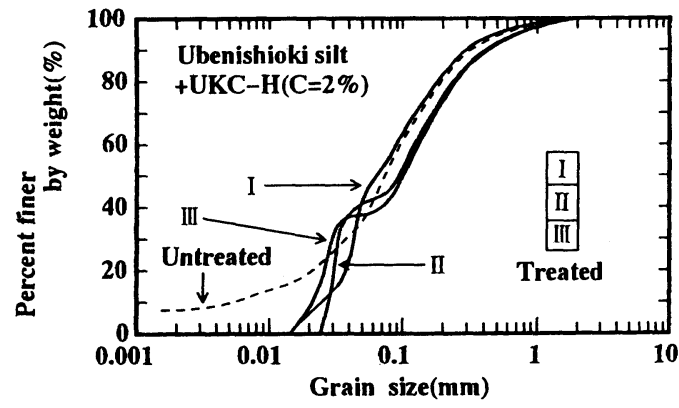

図-16 宇部西沖シルト処理土の粒度分布曲線

い粒子から成る土の処理土では $C-S-H$ だけが 生成し, 一方, 宇部西沖シルトのような細かい粒子 を多く含む土の処理土では $C-S-H$ の他にエト リンガイトが生成していることが確認された. $C-S-H$ は土粒子の表面を覆うように生成する ことを考慮すると, 新宮砂のように粒径が大きく, 均等な土試料では間隙が大きいために, $C-S-H$ の生成によって間隙が減少する割合は 小さい. その結果, すでに述べたように, この砂の 処理土の液状化抵抗の増加はほとんどなく, また一 軸圧縮強度はゼロであると理解される。

次に, セメントの添加によって粒度分布に最も顕 著な変化が認められた宇部西沖シルトについてセメ ント添加前後における粒度曲線の一例を図-16に示 す. 3 本の実線の曲線は処理土供試体の上部 (I), 中央部 (II)，下部(III)に対するものである．破線は 未処理土のそれを示す.この図から分かるように， 処理土では粒径 $0.015 \mathrm{~mm}$ 以下の細粒分が消失し, 階 段状粒度分布になっている. 一方, 当然のことなが ら新宮砂のセメント処理土では顕著な粒度変化は見 られなかった。

\section{5. 結論}

砂〜シルト地盤の液状化対策としてのセメント安 定処理の効果を土の粒度との関係から調べることを 主目的にして繰返し三軸試験機による液状化実験を 行った. 粒度分布の著しく異なる 6 種類の土に 2 種 類のセメントを所要量添加し, 三軸室で 1 日圧密し た処理土供試体を実験の対象にした.

また処理土の応力〜ひずみ関係，液状化抵抗と一 軸圧縮強度の関係の他に処理土の土粒子構造, 粒度 分布を調べた. 得られた結果は, 以下のように要約 することができる.

（1）粗い粒子からなる粒度の悪い新宮砂の場合,
セメント添加率 $C=5 \%$ の場合でもセメント処理の効 果が小さく, せん断時には負のダイレイタンシーに よって間隙水圧が容易に増加して有効応力がゼロと なり，液状化に至る。これに対して，細粒分に富み 粒度の良い宇部西沖シルトの場合, $C=2 \%$ の場合で もセメント処理効果が大きいため, 正のダイレイタ ンシーが発生して, 有効応力が一時的に回復して決 して有効応力がゼロとなることはない.

（2）今回の実験の範囲では処理土の液状化抵抗 増加比 $R L$ (式 (2)) は, 有効径 $D_{10}$ ともっとも良い 相関関倸にあり, $D_{10}$ が小さいほど $R L$ は増加し， その関係はセメント添加率に依存することが明示さ れた．また，その関係は，今回使用したポルトラン ドセメントおよび $U K C-H$ の場合にほとんど同じ ものであった.

（3） $C=5 \%$ であても新宮砂では安定処理の効

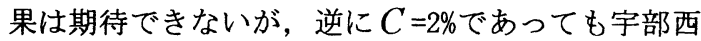
沖シルトではその効果は期待できる.

（4）処理土の一軸圧縮強度は $D_{10}$ と良い相関に ある.また, 処理土の液状化抵抗 $\left(R_{20}\right)_{C}$ と一軸圧 縮強度 $q_{u}$ （単位は $\mathrm{kPa}$ ）の関係は, $\left(R_{20}\right)_{c}=0.0031 q_{u}+0.30$ ( $C=2 \%$ の場合) なる直線 で近似される.

（5）走查型電顕観察によってセメント水和物が 細かい土粒子間を固結させて土粒子構造が安定する ために, 処理土の液状化抵抗および一軸圧縮強度が 増加すると考えられた。したがって，それらの増加 は粒度指数の中で細かい土粒子の大きさを代表する 指数 $D_{10}$ と良い相関関係にあると理解された.

今後は圧密日数を変えた実験を行い，より実用的 であると考えられるセメント安定処理土の液状化抵 抗を求めることが必要である.

謝辞：セメント安定材 $(U K C-H)$ を提供して頂い た（株）カルジード，また，実験とその結果の整理 を手伝って頂いた畑岡直樹君（山口大学大学院）, 北村朋子さん（山口大学工学部）に深く謝意を表し ます。

\section{参考文献}

1) Saxena,S.K., Reddy,K.R. and Avramidis, A.S. : Liquefaction Resistance of Artificially Cemented Sand, Journal of Geotechnical Engineering Division, ASCE, Vol.114, No.12, pp. 1395-1413, 1988.

2) Clough,G.W., Iwabuchi,J., Rad,N.S. and Kuppusamy, T. Influence of Cementation on Liquefaction of Sands, Journal of Geotechnical Engineering Division, ASCE, Vol.115, No.8, pp. 1102-1117, 1989.

3）渡辺則雄, 森 利弘, 濱田尚人：セメント㦟濁液を用 いた液状化対策に関する振動台実験（その 1 要素試 
験による液状化特性），第 27 回土質工学研究発表会 講演集, pp. 1157-1158, 1992.

4）奥村哲夫, 成田国朝, 大根義男 : 人工的にセメンテ ーション効果を与えた砂の非排水繰返し強度, 土質 工学会論文報告集, Vol. 29, No. 2, pp. 169-180, 1989.

5）安田進, 永瀬英生, 古関功一, 島 宏, 松枝弘 喜 : 石灰, セメントを混合した土の液状化強度特性, 第 26 回土質工学研究発表会講演集, pp. 853854, 1991.

6）山本哲朗，大原資生，堀㴊幸司，鈴川俊道：シルト 質砂地盤の液状化対策としてのセメント安定処理, 地 盤と建設, Vol. 11, No. 1, pp. 83-88, 1993.

7）液状化対策の調查・設計から施工まで編集委員会 編：液状化対策の調査・設計から施工まで，土質工 学会, 1993.

8）善 功企, 山崎浩之, 佐藤 泰 : 事前混合処理工法 による処理土の強度・変形特性, 港湾技術研究所報 告, 第 29 巻, 第 2 号, pp. 85-118, 1990.
9）善 功企, 山崎浩之, 渡辺篤史, 芳沢秀明, 玉井章 友：セメント混合した砂質土埋立工法に関する研究 一改良土の基本的特性と混合・埋立実験一，港湾技 研資料, No. 579 , pp. 1-41, 1987.

10) 善 功企：事前混合処理による埋立地盤対策, 土と 基礎, Vol. 42, No. 2, pp. 37-42, 1994.

11) Ōhara,S. and Yamamoto,T. : A Practical Method for Obtaining Correction Factor of Liquefaction Resistance for Membrane Penetration, Soils and Foundations, Vol.31, No.2, pp.188-196, 1991.

12) 善 功企, 舘下 徹, 佐渡篤史, 永井誠二 : 事前混 合処理工法の現地実験における処理地盤の静的およ び動的特性, 土木学会第 48 回年次学術講演会概要集, pp. 500-501, 1993.

13) 日本材料学会, 土質安定材料委員会編 : 地盤改良工 法便覧, 日刊工業新聞社, pp. 142-149, 1991.

(1995. 8. 4 受付)

\section{EFFECT OF GRAIN SIZE CHARACTERISTICS ON THE EFFECTIVENESS OF CEMENT FIXING AGENT METHOD FOR PREVENTING LIQUEFACTION OF SAND TO SILT DEPOSITS}

\section{Tetsuro YAMAMOTO, Tomoya YAMAUCHI and Kouji HORIBUCHI}

To examine the effectiveness of a cement fixing agent method for preventing liquefaction of sand to silt deposits in relation to the characteristics of grain size of soil, liquefaction tests are performed on six cement treated soils consolidated for 1 day in a triaxial cell. Four sands and two silts are treated with ordinary portland cement (OPC) or UKC-H with cement content (C) of $2 \%$ and $5 \%$, respectively.

It is shown that there exists a good correlation between the ratio of increase of liquefaction resistance $R L$ for the treated soils and the effective grain size $D_{10}$, and that the relation depends on content of cement. Furthermore, it is found that the relationships between the liquefaction resistance and the unconfined compressive strength for the treated soils have a linearity 